\title{
Gênero e esteriotipação em Sergio Y. vai à América: Cecilia Coutts em foco
}

\author{
Gender and stereotype in Sergio Y. vai à America: Cecilia Coutts in focus
}

\author{
TÂNIA REGINA OLIVEIRA RAMOS \\ MARINA SIQUEIRA DREY \\ Universidade Federal de Santa Catarina
} Z

\begin{abstract}
Resumo: Materializamos neste ensaio uma leitura da representação da personagem Cecilia Coutts no romance Sergio Y. vai à América, uma narrativa de autoria de Alexandre Vidal Porto, lançada em 2014. Cecilia Coutts ganha nosso interesse na medida em que foi construída em primeiro grau pelo narrador, o psiquiatra Armando, cuja vaidade foi ferida pela percepção da impossibilidade da onipotência da análise clínica, dado a realidade suscetível da trapaça da linguagem - como já havia observado Barthes (1989). O olhar masculino psicologizante, presente na estruturação das personagens, objetifica Cecilia em razão de que a anula enquanto profissional ao se deter na descrição do seu corpo sensual, que distrai e desconcerta o psicólogo, conforme assegura o narrador. É sobre a construção desta imagem sexualizada oriunda da impossibilidade de domínio, por parte do narrador-personagem, sobre esta profissional de sucesso que nos deteremos nesta análise.
\end{abstract}

Palavras-chave: Sergio Y. vai à América; Gênero; Transexualidade; Mulher; Literatura contemporânea

\begin{abstract}
In this essay we materialize a reading of the representation of the character Cecilia Coutts in the novel Sergio Y. vai à America, an narrative written by Alexandre Vidal Porto, launched in 2014. Cecilia Coutts wins our interest by the fact that she was built in first degree by the narrator, the psychiatrist Armando, whose vanity was hurt by the perception of the inability of the omnipotence of clinical analysis, given the likely reality of the language' cheating as already noted Barthes (1989). The psychologizing male gaze, present in the structure of the characters, objectifies Cecilia, focusing in the description of her sensual body, a body which distracts and disturbs the psychologist, as assures the narrator, thus, nullifying her as professional. It's on the building of this sexualized image originated by the impossibility of the domain of this successful professional by the narrator - character, that we will concentrate in this analysis.
\end{abstract}

Keywords: Sergio Y. vai à América; gender; Transgenderism; Woman; Contemporary literature

\section{Introdução}

Para interpretar o romance Sergio Y. vai à América e refletir sobre aquilo que se considerou uma imagem objetificadora da psiquiatra Cecilia Coutts, este ensaio foi dividido em três partes. Coube à primeira a reflexão acerca da literatura brasileira contemporânea a fim de examinar a conjuntura em que está inserido o romance em questão. Para isso, apropriamo-nos de alguns dos postulados de Beatriz Resende (2004, 2008) e de Karl Eric Schollhammer $(2009,2012)$ por acreditarmos que as investigações empreendidas por estes pesquisadores apresentam interessantes considerações a respeito da literatura brasileira atual.

Em seguida, ocupamo-nos em abordar o romance de maneira geral, na medida em que identificamos a importância de contextualizar o recorte a que nos dispomos, dado a ausência de fortuna crítica em torno desta narrativa. Ainda, com intuito de tocar àquilo que foi identificado como "novo realismo" na literatura contemporânea, procuramos traçar um paralelo entre a temática do livro com uma demanda social bastante emergente: a discussão de identidade de gênero. Assim, apresenta-se algumas considerações no tocante ao Projeto 
de Lei de Identidade de Gênero (2013), de autoria dos deputados Érika Kokay e Jean Wyllys.

Em um terceiro momento, partimos para uma leitura mais afunilada do romance; esta se dedica à representação da personagem Cecilia Coutts. Em vista disso, foram resgatadas considerações da professora e pesquisadora Regina Dalcastàgne $(2010,2012)$ em razão de que acreditamos que os resultados quantitativos de sua pesquisa são significativos para as reflexões que dizem às minorias na literatura atual. Seguidamente, examinamos a realização da personagem supracitada para, finalmente, nas Considerações Finais deste trabalho, organizar uma síntese das reflexões alcançadas.

\section{Desenvolvimento}

\subsection{Do lugar de enunciação desta literatura}

É pela fertilidade, qualidade e multiplicidade que a literatura brasileira contemporânea desperta interesse, assegura a crítica, professora e pesquisadora Beatriz Resende (2008). Segundo ela, novas editoras e novos escritores aparecem dia a dia, o que justificaria a quantidade abundante de publicações que se tem atualmente. Isso porque esses novos sujeitos não aguardam o aval das clássicas instâncias de autoridade, a academia e o mercado, para publicarem. No entanto, engana-se quem intui que a profusão de obras resulta em uma produção desprovida de cuidado, pelo contrário, "Em praticamente todos os textos de autores que estão surgindo revela-se, ao lado da experimentação inovadora, a escrita cuidadosa, o conhecimento das muitas possibilidades de nossa sintaxe e uma erudição inesperada [...]" (RESENDE, 2008, p. 17). Soma-se a estas questões a realidade heterogênea desta produção, característica que "[...] se revela na linguagem, nos formatos, na relação que se busca com o leitor [...]" (RESENDE, 2004, p. 18).

Nesta conjuntura, um evidente e relevante deslocamento fica posto, atenta a autora, o de que a escrita contemporânea estabelece

[...] formas de ruptura com heranças ou patrimônios reais e simbólicos que temos carregado, com tradições culturais tributárias de idealizações interessadas em buscar legitimação pela aproximação aos modelos canônicos, próximas a reconhecimentos de subalternidade construídos por valores eurocêntricos que organizam nosso passado cultural (RESENDE, 2014, p. 13).

Dessa forma, abandona-se o método tradicional de buscar "o melhor" da literatura europeia para se elaborar outra arte que não eco daquela vanguarda. Assim, essa literatura passa a ser mais democrática, convergindo com uma dinâmica global, em vez de se circunscrever a uma tradição restrita.

Mesmo nessa possibilidade aberta e heterogênea de produção, Beatriz Resende não deixa de identificar uma constante:

A ruptura com a tradição realista da literatura, não pelo uso de recursos ou formatos próprios da ficção não realista como o absurdo ou o real-imaginário latinoamericano, mas pela apropriação do real pelo ficcional de formas diversas, com a escrita literária rasurando a realidade que, no entanto, a incorpora (RESENDE, 2014, p. 14).

Esta recorrência também é observada por outros teóricos que se debruçam sobre a escrita contemporânea, a exemplo do professor e pesquisador Karl Eric Schollhammer, quando defende que a literatura atual inscreve um novo realismo expresso

[...] pela vontade de relacionar a literatura e a arte com a realidade social e cultural da qual emerge, incorporando essa realidade esteticamente dentro da obra e situando a própria produção artística como força transformadora. Estamos falando de um tipo de realismo que conjuga as ambições de ser "referencial", sem necessariamente ser representativo, e ser, simultaneamente, "engajado", sem necessariamente subscrever nenhum programa político ou pretender transmitir de forma coercitiva conteúdos ideológicos prévios (SCHOLLHAMMER, 2009, p. 54).

Assim, esta proposta deixa para trás a imagem do realismo histórico, que se aproxima de uma alegoria pictórica do visível, para registrar formas de realismo que buscam visualidades. Isto é, no lugar de reivindicar verossimilhança por meio de abundâncias descritivas, passa-se a valorizar a presença performática e transformadora da linguagem.

Este movimento pode ser compreendido pelo sentimento de anacronia, para usar os termos de Giorgio Agambem (2009), experimentado por aquele que é contemporâneo. Anacronia, vale ressaltar, não em uma perspectiva vulgar, no sentido de "dar as costas" para o seu tempo e se deixar tomar por outro, mas em uma proposta em que o eu, no meu próprio tempo, toma consciência dos outros; é por isso que o contemporâneo é capaz de captá-lo, o tempo, por reconhecer nele uma defasagem, uma diferença. Nas palavras de Agambem (2009, p. 59, grifos do autor): "A contemporaneidade, portanto, é uma singular relação com o próprio tempo, que adere a este e, ao mesmo tempo, dele toma distâncias; mais precisamente, essa é a relação com o tempo que a este adere através de uma dissociação e um anacronismo." A este respeito, Shollhammer (2012, p. 19) defende que 
O escritor contemporâneo parece ser motivado por uma grande urgência. A urgência de se relacionar com a realidade histórica, mesmo reconhecendo a impossibilidade de captá-la na sua especificidade atual, em seu presente. Daí que os escritores se sentem anacrônicos em relação ao presente, e passam a aceitar que sua "realidade" mais real só poderá ser refletida na margem e nunca enxergada de frente ou capturada diretamente. A crítica da literatura brasileira contemporânea ressalta insistentemente o traço da presentificação na produção atual. Expressa-se no imediatismo de seu próprio processo criativo, na facilidade de chegar da escrita à publicação por via da divulgação digital que muitas vezes antecipa a chegada ao papel. A prosa gira em torno de temas próximos no tempo e no espaço, daquilo que nos acontece agora, da experiência de pessoas e de grupos da atualidade com traços fortemente biográficos ou autobiográficos. Mas a procura do presente também é percebida na ansiedade de articular e de intervir de modo efetivo sobre uma realidade presente conturbada.

Fica posto, em vista disso, que a literatura contemporânea não poderia abdicar de pautas atuais e pertencentes à sociedade moderna, dado a possibilidade do contemporâneo de captar seu tempo, justamente pela defasagem, pela diferença, pelo supracitado anacronismo. Por conseguinte, engajamento e intimismo entrelaçam-se em prol de narrativas heterogêneas que se dispõem a problematizar temáticas comuns a esta presentificação.

É nessa conjuntura que se inscreve o romance Sergio Y vai à América quando se dispõe a contar a história de um psiquiatra que retorna, por intermédio da memória, a um antigo caso clínico que, bem verdade, nunca o abandonou. Exílio, relação de gênero, felicidade, testemunho, poder monetário e identidade sexual imbricam-se nesta narrativa que responde, impreterivelmente, ao século XXI.

\subsection{Do romance}

Arriscamos afirmar que se anuncia na capa a mais objetiva síntese deste romance, que desde o título destaca um personagem crucial para o desenrolar do enredo, a julgar pela exteriorização do nome: Sergio. Todavia, a proteção à identidade deste sujeito, sugerida pelo "Y." do sobrenome, insinua uma ambientação de segredo, como uma marca que registra a impossibilidade do leitor em acessá-lo senão aceitando o convite da narrativa, íntimo e privado, uma vez que este encontro se dará entre o leitor e a obra. Esse registro, portanto, resume um pacto de sigilo que, posteriormente, quando na leitura, será identificado na relação entre médico e paciente. Junta-se a isso, o trocadilho imperdível que a inicial do sobrenome permite ao associar o conceito dos cromossomos sexuais $\mathrm{Y}$ $\mathrm{e} \mathrm{X}$ à transexualiade discutida na obra, um corpo nasce $\mathrm{Y}$ enquanto a identidade do seu sujeito é X. Ainda, há o fato do personagem ir à América, e não à Nova York, quer dizer, apenas na "terra prometida" encontra-se a felicidade; o sonho americano vive. Para finalizar, dois nomes próprios: a logomarca da Companhia Das Letras registra o espaço de prestígio através do qual o autor, o diplomata Alexandre Vidal Porto, irá se enunciar. Está mapeado o romance.

Ao seguir narrativa adentro, todavia, fica claro que para cada rota proposta outros tantos caminhos existirão, pois o narrador, a contar setenta anos de idade, revela a história com base no instrumento da memória, reconhecendo que esta “[...] apaga e seleciona." (PORTO, 2014, p. 67). Assim, fragmento e lacuna são reivindicados por via da fabulação, uma vez que a memória requer uma participação emocional àquilo que se deu no passado, sendo, por isso, parcial, incompleta e tendenciosa, pois ela "[...] faz com que os dados caibam em esquemas conceituais, reconfigura sempre o passado tendo por base as exigências do presente." (ROSSI, 2010, p. 28).

Sob esta condição, o leitor é convidado a compartilhar os desdobramentos que Sergio Y. desencadeou na vida do experiente e renomado psiquiatra, Armando, cuja vaidade foi ferida pelo abandono do paciente sem, antes disso, ter notado sua disforia sexual; realidade que conheceu apenas quando na morte de Sergio, que se revelou, portanto, Sandra. É diante deste fracasso profissional que o psiquiatra, inconformado, sai em busca da narrativa de vida daquele paciente e, posteriormente, dá-se ao direito de compartilhar esta história com a justificativa de que, com isso, buscava se tornar "[...] um médico melhor e um ser humano mais íntegro." (PORTO, 2014, p. 17).

O romance em questão é o segundo livro de Alexandre Vidal Porto, que em 2005 publicou Matias na Cidade, pela Editora Record. Sergio Y. vai à América ganhou destaque pela primeira vez em 2012 quando foi vencedor do Prêmio Paraná de Literatura daquele ano, concurso que objetiva a seleção de livros inéditos "[...] que não tenham sido objeto de qualquer tipo de apresentação, veiculação ou publicação parcial ou integral antes da inscrição no Concurso até a divulgação do resultado e entrega dos prêmios." (EDITAL PRÊMIO PARANÁ DE LITERATURA, 2012). Com isso, diante da visibilidade do Prêmio Manoel Carlos Karam, denominação da condecoração destinada à primeira colocação na categoria romance, Alexandre assinou contrato com a Companhia das Letras e, em 2014, publicou a narrativa.

A obra conta com 181 páginas nas quais 21 capítulos se dividem. Curtos e não numerados, norteiam o leitor pelos títulos dúbios que, por um lado, permitem o acesso geral do conteúdo que ali se materializa e, por outro, cria uma espécie de jogo com os sentidos móveis dos vocábulos, de forma que a interpretação, portanto, oscila entre a realidade conotativa e denotativa da língua. Exemplificamos esta questão com o primeiro capítulo, no qual a ambiguidade é construída com auxílio do layout 
da folha, que contém o título no topo do anverso: "Tudo o que você precisa saber sobre mim", seguido de uma página em branco. Somente na folha seguinte o narrador inicia o relato acerca de si, cujo discurso ele mesmo organiza, vale lembrar.

Dessa forma, o "tudo" que o leitor deve saber será mediado pelo narrador, conforme suas pretensões. Quer dizer, o título na página em branco pode sugerir que o leitor não terá acesso ao que realmente seria pertinente tomar conhecimento. Parece-nos possível ainda, em outra aproximação, relacionar o silêncio à psiquiatria como se fosse uma pausa de um sujeito para organizar a fala, no caso, a do próprio narrador que se coloca no divã na busca por compreensão e superação daquilo que se configurou como um trauma para sua vida, inesperado e decisivo para um profissional renomado de 70 anos. O movimento, portanto, é previsto pela análise clínica de orientação psicanalítica - não por acaso, corrente teórica na qual o personagem se inscreve - que reconhece a fala do sujeito sobre o outro como uma fala de si mesmo, isto é, quando o sujeito fala do outro ele está falando de si.

O foco narrativo em primeira pessoa, cadenciado e envolvente, conquista pelo caráter confessional que o relato detém, fazendo do leitor quase um amigo a quem o narrador confia um segredo. O romance, a nosso juízo, é um típico caso de "escrita cuidadosa" que conhece as "muitas possibilidades de nossa sintaxe", para usar os termos de Beatriz Resende (2008, p. 18). Alexandre Vidal Porto faz jus à condição de diplomata que, do lugar de erudição de onde fala, tem consciência exata dos meandros da linguagem.

A obra também se insere no rol de narrativas que trabalham com a noção do novo realismo, sobre o qual fala Karl Eric Schollhammer (2009, p. 53-54), na medida em que não se perde na proposta do "[...] realismo tradicional e ingênuo em busca da ilusão de realidade." e nem em "[...] um realismo propriamente representativo" ao trazer para o enredo o tema da transexualidade, ainda tão caro e deturpado no país. Exemplo disso é a repercussão que o Projeto de Lei de Identidade de Gênero (PL $5002 / 2013$ ) ou Lei João Nery ${ }^{1}$, de autoria dos deputados e Érika Kokay (PT/DF) e Jean Wyllys (PSOL/RJ), vem recebendo. O projeto, que dispõe sobre o direito à identidade de gênero e altera o artigo no 58 da Lei 6.015 de 1973, dentre outras medidas, decreta:

Artigo 3ำ Toda pessoa poderá solicitar a retificação registral de sexo e a mudança do prenome e da imagem registradas na documentação pessoal, sempre que não coincidam com a sua identidade de gênero auto-percebida.

O Projeto foi assim nomeado em homenagem a João W. Nery primeiro trans a ser operado no Brasil.
Artigo 4o Toda pessoa que solicitar a retificação registral de sexo e a mudança do prenome e da imagem, em virtude da presente lei, deverá observar os seguintes requisitos: I - ser maior de dezoito (18) anos; II - apresentar ao cartório que corresponda uma solicitação escrita, na qual deverá manifestar que, de acordo com a presente lei, requer a retificação registral da certidão de nascimento e a emissão de uma nova carteira de identidade, conservando o número original; III - expressar o/s novo/s prenome/s escolhido/s para que sejam inscritos. [...]

Artigo 5을 Com relação às pessoas que ainda não tenham dezoito (18) anos de idade, a solicitação do trâmite a que se refere o artigo 4 을 deverá ser efetuada através de seus representantes legais e com a expressa conformidade de vontade da criança ou adolescente, levando em consideração os princípios de capacidade progressiva e interesse superior da criança, de acordo com o Estatuto da Criança e do Adolescente (KOKAY; WILLYS, 2013, p. 01).

Segundo seus redatores, este projeto baseia-se na Lei 26.743 da Argentina, a mais significativa e avançada no mundo em termos de identidade de gênero "[...] já que reflete os debates políticos, jurídicos, filosóficos e éticos travados a respeito do assunto nos últimos anos" (KOKAY; WILLYS, 2013, p. 12). Em vigor desde o ano de 2012, foi aprovada por unanimidade no Senado e pela maioria na Câmara dos Deputados. Tendo, ainda, o apoio da presidenta Cristina Kirchner. No Brasil, entretanto, vem sendo alvo de deturpações e simplificações que apavoram os desavisados e alimentam os discursos de intolerância dos fundamentalistas que chegaram a alegar, conforme relata o deputado Jean Wyllys em sua página oficial na internet $<$ http://jeanwyllys.com.br $>$, que o projeto tinha a intenção de obrigar as crianças a mudarem de sexo, ou que os pais, a partir dela, poderiam obrigar seus filhos a fazerem esta mudança.

Em justificativa ao Projeto os deputados argumentam:

Travestis, transexuais, transgêneros e intersexuais não têm como se esconder em armários a partir de certa idade. Por isso, na maioria dos casos, mulheres e homens trans são expulsos de casa, da escola, da família, do bairro, até da cidade. A visibilidade é obrigatória para aquele cuja identidade sexual está inscrita no corpo como um estigma que não se pode ocultar sob qualquer disfarce. E o preconceito e a violência que sofrem é muito maior. Porém, de todas as invisibilidades a que eles e elas parecem condenados, a invisibilidade legal parece ser o ponto de partida. [...]

Falamos de pessoas que se sentem, vivem, se comportam e são percebidas pelos outros como homens ou como mulheres, mas cuja identidade de gênero é negada pelo Estado, que reserva para si a exclusiva autoridade de determinar os limites exatos 
entre a masculinidade e a feminidade e os critérios para decidir quem fica de um lado e quem do outro, como se isso fosse possível. Travestis, transexuais e transgêneros sofrem cada dia o absurdo da lei que lhes nega o direito a ser quem são. E andam pelo mundo com sua identidade oficialmente não reconhecida, como se, das profundezas da história dos nossos antepassados filosóficos gregos, Crátilo voltasse a falar para Hermógenes: "Tu não és Hermógenes, ainda que todo o mundo te chame desse modo" (KOKAY; WILLYS, 2013, p. 06-07).

Ciente desta realidade marginal, Alexandre Vidal Porto concebe Sandra fora do país. Mais do que isso, estrutura seu romance de forma que o mote do enredo seja a transexual, mas que, efetivamente, a própria narração de Armando seja o objeto central no livro. Quer dizer, nem na obra, a realidade trans pode ser lida no centro, nesse sentido, parece-nos possível identificar a construção de uma dupla negação, intencionando demarcar que não basta a visibilidade, ela precisa estar acompanhada da legitimidade para que possa fazer a diferença.

É com essa sensibilidade que o novo realismo quer se fazer na obra, o impacto transformativo não existe pela via da hostilidade física a qual Sandra poderia ter sido exposta nas ruas violentas e transfóbicas de São Paulo. Ele existe, por exemplo, nas declarações dos pais da jovem que, ricos e instruídos, se veem inconformados com a identidade de gênero da filha: "Eu gerei duas monstruosidades: um anencéfalo e um transexual." (PORTO, 2013, p. 155), declarou o pai de Sandra a Armando. "Quando soube da sua transexualidade, meu primeiro pensamento foi de fracasso. Eu gerava coisas imperfeitas, incompletas. Meu ventre não era profícuo. Era mal-acabado, sub-humano, pensei." (PORTO, 2013, p. 174), revelou a mãe de Sandra, que para os pais volta a ser Sérgio depois da morte prova explícita de que os antepassados não precisam vir tão das profundezas do tempo, como satirizou o texto do Deputado Jean Wyllys e da Deputada Érika Kokay, para nos dizer quem somos.

\subsection{Dos desdobramentos até Cecilia}

A afirmação anteriormente feita de que a história de Sergio/Sandra serve como motivação para que o narrador teça uma narrativa sobre si e se faça, ele mesmo, o eixo central do romance, vira alegoria para a fala da pesquisadora e professora Regina Dalcastàgne (2010, 2012) acerca da representação das minorias na literatura, quando diz que

O silêncio dos grupos marginalizados - entendidos em sentido amplo como todos aqueles que vivenciam uma identidade coletiva que recebe valoração negativa da cultura dominante, sejam definidos por gênero, etnia e cor, orientação sexual, posição nas relações de produção, condição física ou outro critério - é coberto por vozes que se sobrepõem a ele, vozes que buscam falar em nome desses grupos [...]. (DALCASTAGNÈ, 2010, p. 42).

A alegação da pesquisadora diz respeito à autoria, evidentemente, o que também se encaixa no caso do romance em questão, já que Alexandre Vidal Porto fala sobre o lugar da transexualidade e não $d o$ lugar da transexualidade; mas, insistimos, ainda, em tomar a declaração de Regina Dalcastàgne de forma metafórica para assinalar uma segunda sobreposição de vozes, por assim dizer, qual seja a de que o romance faz uso de outro personagem para narrar a experiência da transexualidade, em vez da transexual falar, ela mesma, de si. Ou seja, este sujeito não se enuncia diretamente, pois alguém toma a sua voz, especulando a respeito de sua vida, dificuldades e felicidades, é Armando que se torna mediador deste lugar de existir.

A consideração a respeito da representação dos grupos marginalizados na literatura brasileira foi tecida pela pesquisadora após o resultado de uma investigação que empreendeu na Universidade de Brasília devido à motivação do que identificou como um "[...] sentimento de desconforto causado pela constatação da ausência de dois grandes grupos em nossos romances: dos pobres e dos negros." (DALCASTÀGNE, 2012, p. 147). Para investigar esta invisibilidade, a pesquisadora se propôs a mapear o romance brasileiro contemporâneo cujas obras foram publicadas, de 1990 a 2004, pelas editoras Companhia das Letras, Record e Rocco, recorte editorial que se justificou pelo fato destas figurarem como "[...] editoras centrais no campo literário do período." (DALCASTÀGNE, 2012, p. 151).

É evidente que pesquisas como esta abrem precedente para diversos questionamentos, na medida em que as investigações literárias dificilmente recorrem a métodos quantitativos, pois a literatura comporta um mundo sem fim de variáveis que, ignoradas, podem resultar em uma simplificação que descaracterizaria sua produção. Entretanto, nossa intenção é a de dar luz a certas regularidades que se fazem relevantes para o contexto em que vivemos e, nesse sentido, não se pode ignorar, por exemplo, o fato da pesquisa supracitada identificar $81 \%$ das personagens como heterossexuais, $79,8 \%$ como brancas e, ainda, $71,1 \%$ dos protagonista sendo homens.

É pertinente, ainda, contextualizar esta investigação no que toca às pretensões de Regina Dalcastàgne (2012, p. 149), que além de pesquisadora foi coordenadora do projeto. Diz ela:

[...] a pesquisa não comunga de nenhuma noção ingênua da mimese literária - que a literatura deve servir como espelho da realidade, deve ser o retrato fiel do mundo circundante ou algo semelhante. O problema 
que se aponta não é o de uma imitação imperfeita do mundo, mas a invisibilização de grupos sociais inteiros e o silenciamento de inúmeras perspectivas sociais. A literatura é um artefato humano e, como todos os outros, participa de jogos de força dentro da sociedade. Essa invisibilização e esse silenciamento são politicamente relevantes, além de serem uma indicação do caráter excludente de nossa sociedade (e, dentro dela, de nosso campo literário).

É, portanto, considerando esta realidade que reconhece a literatura em um contexto histórico, situado e datado que insistimos em admitir a relevância desta investigação quando reivindicamos um dos resultados da pesquisa em questão para discorrermos acerca de nossa leitura da personagem Cecilia Coutts. Nele, então, conclui-se que "[...] a narrativa brasileira contemporânea 'moderniza' estereótipos de gênero, em vez de romper com eles.” (DALCASTÀGNE, 2010, p. 62). Esta consideração está ciente de que a condição feminina é múltipla, no sentido de que existem variáveis como classe social, cor, profissão, orientação sexual, contexto cultural e idade, por exemplo, que contribuem para estabelecer distanciamentos relevantes entre as mulheres. $\mathrm{Ou}$, nas palavras de Judith Butler (2003, p.20), “[...] se alguém 'é' uma mulher, isso certamente não é tudo o que esse alguém é [...].”

No entanto, é exatamente à frente desta heterogeneidade que se edifica a afirmativa de Regina Dalcastàgne, uma vez que a avaliação foi cumprida diante dos modelos socialmente estabilizados os quais ignoram a pluralidade do ser mulher em prol de discursos que reverberam padrões historicamente construídos, subordinados a construtos machistas que negam a autonomia e a multiplicidade da mulher. Assim, nesse contexto, por exemplo, são identificadas as mulheres para casar, as mulheres para se divertir e assim por diante, como se a liberdade sexual de cada uma servisse de medida para se identificar aquelas dignas, ou não, do amparo do sujeito soberano masculino.

Em vista disso, estereotipar, acima de tudo, é uma afirmação de controle sobre o corpo da mulher e, por isso, uma ação política. Nela, o corpo feminino é tomado como um território no qual ininterruptas disputas são travadas e distintos discursos reclamados, como se ele, o corpo, fosse uma porção de terra recém descoberta pela qual diferentes países guerrilham.

Esses discursos ganham respaldo na medida em que se formam em lugares legítimos de enunciação, a exemplo dos universos jurídico/legal, médico, econômico e midiático. A grande questão é que, em sua maioria, esses espaços são ocupados em maior número por homens, o que significa que as normatizações de distintos padrões, como o sexual, o emocional e o intelectual serão me- diadas pelo filtro social deste lugar de fala, o do homem. Dessa forma, não importa o quão solidários com a realidade feminina eles sejam, pois nunca estarão neste papel social e, por isso, nunca serão tocados por esta experiência. No caso específico, por mais que Alexandre Vidal Porto integre um grupo marginalizado pela sociedade, os dos homossexuais, e, dessa forma, compreenda o sentimento de estigma, continuará ocupando o papel de homem (branco, culto e bem sucedido, diga-se de passagem).

$\mathrm{Na}$ esfera ficcional, a representação de Cecilia Coutts vem do lugar de um psiquiatra de renome que se apresenta como "[...] um dos melhores médicos desta cidade." (PORTO, 2014, p. 11). "Esta cidade" é São Paulo, local em que reside e trabalha Armando. Viúvo, tem uma filha, Mariana, que mora em Chicago e é casada com um norte-americano. O psiquiatra, por conseguinte, vive sozinho em um apartamento de quatro quartos no rico bairro Higienópolis; por mais que mencione a vontade em ir morar na casa da praia, não fossem os pacientes, pois "Médico sem paciente é ninguém." (PORTO, 2014, p. 15), concorda o narrador com a frase que o pai, e também médico, dizia quando estava vivo.

Armando, ainda, não perde a chance de informar o leitor a respeito de sua distinção intelectual, notada desde a juventude quando concluiu a graduação e foi aceito em um hospital fora do país e de renome: "[...] por conselho de um professor meu na USP, candidatei-me a uma vaga de residente no Mount Sinai Hospital, em Nova York. Nessa época, era muito raro que aceitassem estrangeiros. Para a surpresa de alguns, mas não de todos, me aceitaram." (PORTO, 2014, p. 83).

Com informações desta ordem, o leitor vai apreendendo o discurso do narrador e, no curso do romance, sente-se compartilhando Nova York ao lado dele, de forma que a narrativa engendra realizações verossímeis no tocante às cidades norte e sul americanas sem, todavia, perder-se em descritivismos assépticos e miméticos. Dessa maneira, o realismo dos lugares é construído através dos pequenos gestos de intimidade, reconhecidos nos sujeitos pertencentes àqueles lugares, no caso, Nova York e São Paulo.

Ao longo da narrativa, o leitor ainda se depara com distintas passagens em que o narrador reconhece sua vaidade, tanto abertamente quando, por exemplo, declara: "Orgulho-me do reconhecimento que me concedem. Sou vaidoso, mas isso não me incomoda. Sempre achei a modéstia uma qualidade superestimada." (PORTO, 2014, p.12), quanto nas entrelinhas, como quando revela que ao ser abandonado por um paciente sentia “[...] uma infelicidade profunda: infantil e injustificável. Algo semelhante à impotência que sente uma criança ao 
descobrir que seu brinquedo favorito foi quebrado por outra criança mais nova, sem que nada se possa fazer a respeito." (PORTO, 2014, p. 16).

Nesta revelação, parece-nos impossível não reconhecer uma significação dúbia, já que, por um lado, o narrador estaria admitindo, de maneira geral, não conseguir lidar com o desinteresse dos pacientes quando estes ainda são objetos de sua curiosidade e, por outro lado, indicaria uma referência direta ao caso de Sergio Y. Ambas as considerações parecem-nos plausíveis em razão de que aquela se torna compreensível diante de um lugar de fala de um profissional que faz questão de se incluir no rol dos melhores da cidade, como se a inconformação quisesse dizer: "você sabe com quem está falando?". E esta, por sua vez, dedica-se a registrar, nas entrelinhas, o caso de Sergio Y., pois: i) o paciente suspendeu as consultas com Armando; ii) Sergio passou a se consultar com outra psiquiatra, Cecilia Coutts; iii) Cecilia é mais nova que Armando; iv) Armando ficou obcecado pelo caso; e v) Sergio morreu.

Quer dizer, devido à fixação de Armando por Sergio, o paciente pode ser lido como o seu "brinquedo favorito", o qual foi "quebrado" por Cecilia, "a criança mais nova", devido à simplicidade com que ela lidou com o caso, isto é, metaforicamente, a médica quebra a magia ao não encontrar problemas no caso da transexualidade em questão, tão caro para o narrador que não pode fazer nada em virtude de seu paciente-mistério estar morto. Morto, aliás, antes mesmo de ser empurrado pela janela, morto desde que decidiu ir à Nova York assumir Sandra, a qual o narrador raramente se dirige, pois reforça para o leitor sua dificuldade em admiti-la. Assim, ao longo do romance, delineia uma identidade masculina para a personagem, reforçada com o nome biológico e com os pronomes no masculino.

Cecilia ganha vida no relato do psiquiatra quando este começa uma jornada obsessiva atrás da narrativa existencial do ex-paciente, empreitada motivada pela revelação de que ele havia morrido dois anos após se assumir como Sandra. Dessa forma, em um contexto que ultrapassa a barreira da razoabilidade entre curiosidade e fixação, Armando telefona à mãe da recém-morta a fim de colher informações para compreender este caso não diagnosticado. Deste telefonema, consegue o e-mail da psiquiatra a qual Sandra recorreu quando passou a viver em Nova York.

Com 30 anos a menos que Armando, Cecilia é uma terapeuta bem sucedida, conclusão que o leitor chega após reunir os farrapos de informação deixados pelo narrador acerca desta carreira sólida, a exemplo do amplo consultório em um bairro de status na cidade, da agenda cheia e dos congressos em que participa. Indício velado da consciência desta competência, ainda, é o temor relatado pelo narrador diante da possibilidade do encontro pessoal com a médica:

Posterguei esse dever quanto pude. Três dias antes de minha partida, no entanto, escrevi-lhe um e-mail apresentando-me e perguntando se, durante o curto período que eu passaria em Nova York, ela estaria disponível para uma conversa rápida sobre um expaciente em comum.

Ao procura-la, dava início ao cumprimento de meu dever profissional. No fundo, porém, esperava que a pouca antecedência do pedido inviabilizasse qualquer possível encontro.

A despeito de minha esperança, na manhã seguinte ao envio de minha consulta, encontrei a seguinte mensagem de Cecilia Coutts na minha caixa de entrada:

Caro Dr. Armando ${ }^{2}$,

Teria prazer em encontrá-lo para um café. O senhor poderia vir ao meu consultório nesta quinta-feira, às dez horas da manhã?

Cordialmente,

C. Coutts

Médica Ph. D.

73, Barrow Street, NY, NY - 10014

$\mathrm{O}$ tom amistoso de sua mensagem me intrigou. Que tipo de mulher ela seria? (PORTO, 2014, p. 89-90).

Salienta-se a preocupação do narrador em registrar dúvida frente ao tipo de mulher, e não de médica, que Cecilia seria. Mais do que isso, chama atenção a suposta motivação que resultou nesta indagação: o tom amistoso da psiquiatra. Aliado à declaração anterior de que aguardava uma recusa diante do apertado prazo para o encontro, este comentário parece participar a uma proposta de desacreditar a médica, em razão de que sugere uma simpatia, presumidamente, não correspondente a uma psiquiatra "de respeito", insinuação praticada por um dos melhores médicos de um grande centro, registrase nas entrelinhas para o leitor. Assim, o narrador começa a construir uma imagem que questiona as atitudes sociais da médica, por assim dizer, embutindo na interpretação do leitor certa maledicência quanto ao comportamento de Cecilia.

A primeira consideração tecida pelo narrador sobre o a reunião profissional com a médica afirma:

Cecilia Coutts era muito mais atraente do que eu havia imaginado. Seus lábios eram finos e seu sorriso parecia sincero. Media cerca de 1,70 metro e tinha cabelos pretos e lisos que faziam moldura ao seu rosto

\footnotetext{
2 Dear Dr. Armando,

I would be glad to meet you for coffe. Could you come to my office this coming thursday, at 10 a.m.?

Best regards, C. Coutts, M.D., Ph.D. 73 Barrow Street, NY, NY - 10014.
} 
de traços bonitos. Devia ter cerca de quarenta anos, o que igualmente me surpreendeu. Talvez achasse que, por dividirmos o mesmo paciente, dividiríamos a mesma idade também. Recebeu-me com um aperto de mão. Provavelmente por causa do dia de calor que se anunciava, vestia uma camiseta sem manga e - impossível não notar - não usava sutiã (PORTO, 2014, p. 103).

O início do relato indica que o imaginário do corpo da terapeuta existia antes mesmo de Armando conhecê-la pessoalmente - "Cecilia Coutts era muito mais atraente do que eu havia imaginado." Dessa forma, a menção aos seios da psiquiatra faz parte de um conjunto de idealizações que o personagem-narrador parece construir previamente: o rosto, o corpo, a altura, a idade, o peso, a beleza etc. Assim, a justificativa de ser "impossível não notar" a blusa sem sutiã cairia por terra, no sentido de parecer acidental, como se ele não tivesse intenção de reparar neste fato. Mais ainda, como se a própria Cecilia quisesse que esta percepção acontecesse, a considerar a justificativa do narrador, entre travessões, indicando quase uma imposição da médica em destacar o seu corpo.

Tal consideração endossa o imaginário comum da mulher que pede para ser vista, que provoca o sexo oposto para seduzi-lo; concepção que faz parte de uma construção histórica na qual o corpo feminino é sujeitado ao olhar masculino e manipulado de forma a inferiorizar a imagem da mulher, na medida em que se edifica um discurso no qual seu lugar é o de objeto. A respeito do corpo das mulheres Bourdieu (1999, p. 82) comenta que se faz crer que "[...] elas existem primeiro pelo e para, o olhar dos outros, ou seja, enquanto objetos receptivos, atraentes e disponíveis."

É curioso que o narrador recorre aos aspectos físicos da psiquiatra quando ela se manifesta com propriedade e segurança profissional acerca da identidade de gênero da paciente em questão, como quando Cecilia fala da transexualidade de Sandra, declarando que ela era "[...] um caso inequívoco de disforia sexual" (PORTO, 2014, p. 104, grifo nosso) e o narrador dispara: “[...] mas meus olhos me traíam. Contra minha vontade, insistiam em voltar à marca dos mamilos da dra. Coutts através da sua camiseta branca sem mangas." (PORTO, 2014, p. 108). Ou quando retorna pela última vez ao consultório da psiquiatra e registra para o leitor: "Coutts usava uma camiseta idêntica à do dia anterior, só que de outra cor. Seus mamilos continuavam no mesmo lugar, marcando a malha vermelha." (PORTO, 2014, p. 112).

Assim, parece-nos que a insistência em demarcar a perturbação de Armando frente ao corpo de Cecilia registra uma tentativa de se deslocar a questão central do encontro: Armando foi buscar em Cecilia as respostas para sua falha profissional, e não ao contrário. Em vista disso, se for para determinar um sujeito que está subordinado à competência profissional de outro, este alguém é Armando, que apenas no final da carreira deuse conta da impossibilidade da onipotência da análise clínica, uma vez que a linguagem não consegue apreender a totalidade do sujeito.

No entanto, o narrador engendra uma descrição que se configura como uma violência simbólica, nos termos de Bourdieu (1999), uma vez que constrange moralmente a representação da psiquiatra ao ignorar sua competência intelectual em prol de uma construção que a reduz a um corpo objetificado de mulher sensual, insinuando que o respaldo profissional da médica seja oriundo de seus atributos físicos que desconcertam competentes profissionais como ele, impedindo-os de competir de igual forma com ela, em razão da distração que esta causa.

Esta hipersexualização do corpo de Cecilia registra uma ruptura no ritmo da narrativa que responde à tentativa do vaidoso médico em não admitir o sucesso profissional da terapeuta com Sandra, de forma que ele foca suas impressões no corpo da médica para desviar de si a falha em diagnosticar a paciente em comum. Isto é, imediatamente antes da entrada no consultório, Armando se mostrou obcecado em seguir os passos de Sandra: "Seu dedo tocara o mesmo botão do interfone que eu tocaria. Sua mão tomara a mesma maçaneta de latão que minha mão tomava [...]" (PORTO, 2014, p. 100). No entanto, quando está na presença de Cecilia, vê-se diante do sujeito que compreenderá, melhor do que ninguém, a trapaça, o logro e o jogo, para usar as palavras de Barthes (1989), da linguagem. Assim, Armando se viu deslocado do papel de Deus que atribuía a si mesmo, pois ficou diante de uma encenação da linguagem que não deu conta de interpretar. Dessa forma, frente à impossibilidade de demonstrar conhecimento de causa do caso de Sergio/Sandra acaba por reivindicar o lugar-comum da mulher sedutora.

Nessa altura, precavido é o leitor que trouxe à mente Dom Casmurro e colocou em xeque as declarações deste narrador desde o início do romance. Quer dizer, ousamos pensar que o narrador construído por Alexandre Vidal Porto aproxima-se daquele famoso, já casmurro, Bento Santiago, quando caminha pelas linhas sugestivas de seu testemunho em favor de uma verdade que só pode ser lida a partir de sua enunciação. Armando e Bento são vaidosos e discretos. Ambos propõem suas narrativas em razão de um revés da vida, o de Bento Santiago é a hipotética traição de Capitu e o de Armando é o caso não diagnosticado de Sergio. Cada um, a sua maneira, advoga em favor de fatos, mas que parecem, antes de tudo, móveis, "fatos móveis", para convencer o leitor de suas humildes condições que, no fundo, registram uma insolência e petulância que evidencia a não superação dos ocorridos nos dois casos: Bento não aguenta a 
esposa feminista. Machista, não consegue seguir ao lado de uma mulher decidida e insubordinada. Armando, por sua vez, foi pego na encenação da linguagem, no jogo em que se vê rei, mas é peão. No entanto, ao se fazer narrador de sua história se mostra articulado, um verdadeiro armador.

\section{Considerações finais}

Procuramos apresentar neste trabalho proposições que justificassem a máxima de que a literatura brasileira contemporânea edifica-se a partir de uma materialidade que foge a sistematizações e, por isso mesmo, aponta para uma nova estética que não quer ser fechada, uniforme. A respeito desta característica de abertura, Beatriz Resende assegura que essa heterogeneidade vem a ser um ponto digno de observação nesta literatura peculiarmente fértil e de qualidade.

O pesquisador Karl Eric Schollhammer, por sua vez, identifica nesta produção atual uma recorrência que denominou de o "novo realismo", na medida em que esta literatura contemporânea parece abdicar da imagem do realismo histórico, que se aproxima de uma alegoria pictórica do visível, para registrar formas de realismo que passam a valorizar a presença performática e transformadora da linguagem.

Neste contexto profícuo, todavia, Regina Dalcastègne aponta para o fato de que a representação da condição feminina ainda mostra que esta produção atual mantém estereótipos de gênero, modernizando-os em vez de abdicar deles. Conforme, portanto, foi demonstrado na representação da personagem Cecilia Coutts, uma psiquiatra de sucesso que manteve o papel da mulher sensual que desestabiliza o seu entorno devido a sua condição física.

No caso específico, portanto, é plausível considerar que a representação da personagem Cecilia Coutts está concatenada à sua insubordinação intelectual a Armando, dado a segurança profissional com que lidou com o casofracasso do vaidoso colega de profissão. Assim, diante da impossibilidade de domínio de Cecilia, uma vez que a linguagem instaura uma relação direta de poder, Armando deixou em segundo plano a erudição da terapeuta em prol de uma narração que privilegiou o transtorno que, segundo ele, a condição física dela desencadeou.

Dessa forma, a narrativa continua perpetuando o estereótipo da mulher sensual e integra, em vista disso, o rol de romances que apenas modernizam, mas continuam reforçando o lugar-comum do gênero, servindo de exemplo, ainda, às considerações da professora e pesquisadora Susana Bornéo Funck (2003, p. 476) quando diz que as representações das mulheres não têm uma "[...] real liberação da sensualidade, uma vez que a mulher é idealizada e que a construção cultural do desejo masculino traz embutida a noção de conquista e dominação".

\section{Referências}

AGAMBEM, Giorgio. O que é o contemporâneo? E outros ensaios. Trad. Vinícius N. Honesko. Chapecó: Argos, 2009. p. 55-73.

BARTHES, Roland. Aula. Trad. Leyla Perrone-Moisés. São Paulo: Cultrix, 1989.

BOURDIEU, Pierre. Dominação Masculina. Trad. Maria Helena Küher. Rio de Janeiro, Bertrand Brasil, 1999.

BUTLER, Judith. Problemas de gênero: feminismo e subversão da identidade. Rio de Janeiro: Civilização Brasileira, 2003.

DALCASTAGNÉ, Regina. Representações Restritas: a mulher no romance brasileiro contemporâneo. In: DALCASTAGNÉ, Regina; LEAL, Virgínia Maria Vasconcelos (Org.). Deslocamentos de gênero na narrativa brasileira contemporânea. São Paulo: Editora Horizonte, 2010. p. 40 -64.

. Literatura brasileira contemporânea: um território contestado. Rio de Janeiro, Vinhedo: Editora Horizonte, 2012.

EDITAL PRÊMIO PARANÁ DE LITERATURA. Paraná, 2012. Disponível em: <http://www.cultura.pr.gov.br/arquivos/File/ biblioteca_publica/Edital_Premio_Parana_de_Literatura_2012. pdf $>$. Acesso em: 27 ago. 2015.

FUNCK, Susana Bornéo. O jogo da representação. In: BRANDÃO, Izabel; MUZART, Zahidé (Org.). Refazendo nós: ensaio sobre mulher e literatura. Florianópolis: Editora Mulheres, 2003. p. 475-481.

KOKAY, Érika; WILLYS, Jean. Projeto de Lei 5002, 2013. Dispõe sobre o direito à identidade de gênero e altera o artigo 58 da Lei 6.015 de 1973. Disponível em: < http://www.camara. gov.br/proposicoesWeb/prop_mostrarintegra?codteor=1059446 \&filename $=P L+5002 / 2013>$. Acesso em: 29 ago. 2015.

PORTO, Alexandre Vidal. Sergio Y. vai à América. São Paulo: Companhia das Letras, 2014.

RESENDE, Beatriz. A literatura brasileira na era da multiplicidade. In: RESENDE, Beatriz (Org.). Contemporâneos: expressões da literatura brasileira no século XXI. Rio de Janeiro: Casa da Palavra: Biblioteca Nacional, 2008. p. 15-40.

SCHOLLHAMMER, Karl Erik. Ficção brasileira contemporânea. Rio de Janeiro: Civilização Brasileira, 2009.

. Para uma crítica do realismo traumático, Soletas, n. 23, p. 19-28, 2012.

Recebido: 18 de abril de 2016 Aprovado: 15 de outubro de 2017 Contato: taniareginaoliveiraramos@gmail.com (Tânia Regina Oliveira Ramos) marinasikeira@hotmail.com (Marina Siqueira Drey) 